\title{
Pull Off test to evaluate the compressive strength of concrete: an alternative to Brazilian standard techniques
}

\section{Ensaio de "Pull Off" para avaliar a resistência à compressão do concreto: uma alternativa aos ensaios normalizados no Brasil}

\begin{abstract}
To estimate the compressive strength of concrete is necessary in many reinforced concrete structures inspection works. In Brazil, the standard tests for this purpose are: Compressive test in drilled cores, rebound hammer test and ultrasonic test. In the United States and Europe are also regulated other techniques. The aim of this paper is to analyze the use of Pull Off test as an inspection tool of concrete and also disclose the possibility of use of complementary techniques to the standard ones in Brazil. The results show that the Pull Off test results in high correlation $\left(R^{2}>0.93\right)$ with the compressive strength, measured in cylindrical and prismatic specimens. The rebound hammer test did not show satisfactory correlation $\left(R^{2} \cong 0.6\right)$ for the case of cylindrical specimens. The ultrasonic test showed high correlation $\left(R^{2}>0.98\right)$, but behaves differently with the shape changing of the specimens.
\end{abstract}

Keywords: nondestructive test, concrete strength, rebound hammer test, ultrasonic test, Pull Off.

\section{Resumo}

Estimar a resistência à compressão do concreto é uma necessidade em muitos trabalhos de inspeção de estruturas de concreto armado. No Brasil, as ferramentas regulamentadas pela ABNT para este fim são a extração de testemunho, a esclerometria e o ultrassom. Nos Estados Unidos e Europa também são regulamentadas outras técnicas. O objetivo deste trabalho é estudar a viabilidade do uso do ensaio de "Pull Off" como ferramenta de inspeção em concreto e ainda divulgar a possibilidade de emprego de técnicas complementares as normalizadas no Brasil. Os resultados demonstram que o ensaio "Pull Off" apresenta alto índice de correlação $\left(R^{2}>0,93\right)$ com o resultado de resistência à compressão medido tanto em corpos de prova cilíndricos como nos prismáticos. A técnica de esclerometria não apresentou correlação satisfatória $\left(R^{2} \cong 0,6\right)$ para o caso de corpos de prova cilíndricos e o ultrassom apresentou alta correlação $\left(R^{2}>0,98\right)$, mas se comporta diferente com a mudança de forma dos corpos de prova.

Palavras-chave: ensaios não destrutivos, resistência do concreto, esclerometria, ultrassom, "Pull Off".

Universidade Federal do Paraná, engenheiroeduardopereira@gmail.com, Curitiba, Brasil;

Universidade Federal do Paraná, medeiros.ufpr@gmail.com, Curitiba, Brasil. 


\section{Introduction}

In reinforced concrete structures, the strength of concrete is one of the most important properties, being the main parameter used for design. Ways to evaluate this property in finished structures or structures in use, without damage to its functionality or appearance, have been the concern of engineering professionals over the years. In civil engineering there are many test methods to evaluate the strength of concrete. The most frequently used test is to measure the compressive strength of concrete at age of 28 days using simple compression in cylindrical and prismatic specimens. The simple compression test on cylindrical specimens is standard both in Brazil and the USA [1, 2], and in Europe, both shapes are standardized $[3,4]$.

Despite the ease of implementing this kind of test, both in terms of specimen preparation as well as in getting results, the test requires planning before the execution of structures, through the creation of test specimens. This fact does not favor the inspections in finished structures or control the development of the material resistance over time.

In recent decades, other tests were developed, like non-destructive tests which, through faster, simplest and more economical processes allow obtaining information on the concrete properties. These tests also provide an estimate for the compression strength of the measured concrete in situ, eliminating the need of extraction of many specimens for determination of the compressive strength of the inspected structures. The most popular tests are the rebound hammer and the ultrasound test, which are standard in Bra- zil. There are also others tests such as penetration resistance of hardened concrete, Pull Off, Pull Out and Break Off, presenting themselves as viable alternatives $[5,6,7,8,9,10]$.

The non-destructive techniques produce little or no damage to the inspected part, can be implemented in concrete structures in use and allow the detection of problems still in early stages. This can be an advantage, especially from a financial perspective, because when a problem is detected at an early stage the necessary interventions can be done before the complete damage of the structure. The choice of the test method depends on several factors such as structure access, cost of intervention, damage caused during the execution of the test, speed of execution, characteristics and type of assessment to be achieved [9]. This paper discusses the rebound hammer test [11] and the ultrasound test [12], standardized in Brazil, in addition to the Pull Off test, as standardized in Europe by BS 1881 part. 207 [13]

\section{Non-destructive test}

\subsection{Rebound hammer test}

Currently, the non-destructive and most commonly used test is the rebound hammer test. This method is based on measuring the surface hardness of the concrete and, as the response variable, has an index that can be used to estimate the resistance from correlation curves. The rebound hammer is portable, simple and inexpensive. This equipment enables the fast acquisition of a large amount of data.

The equipment consists of a cylindrical tube in whose interior there

Figure 1 - Rebound Hammer test (14)

(a)

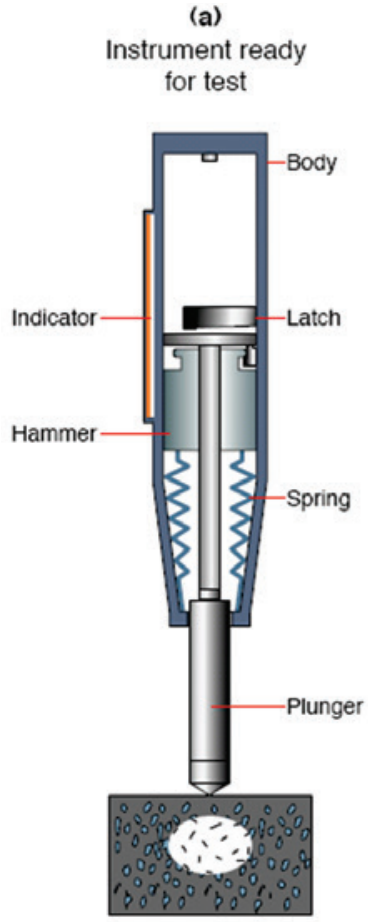

(b)

Body pushed toward test object (c)

Hammer is released (d)

Hammer rebounds
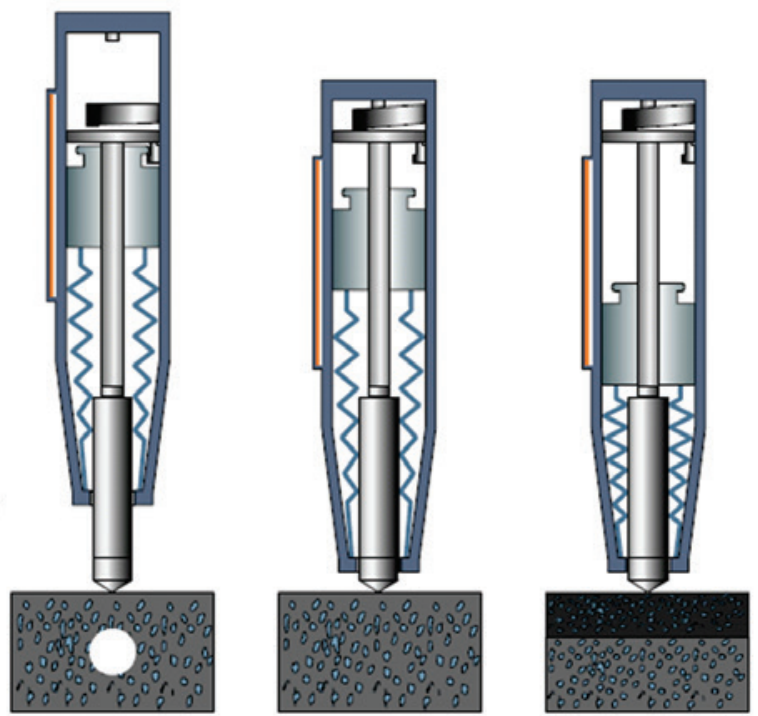


\section{Figure 2 - Example of correlation between compressive strength in extracted specimens and rebound number}

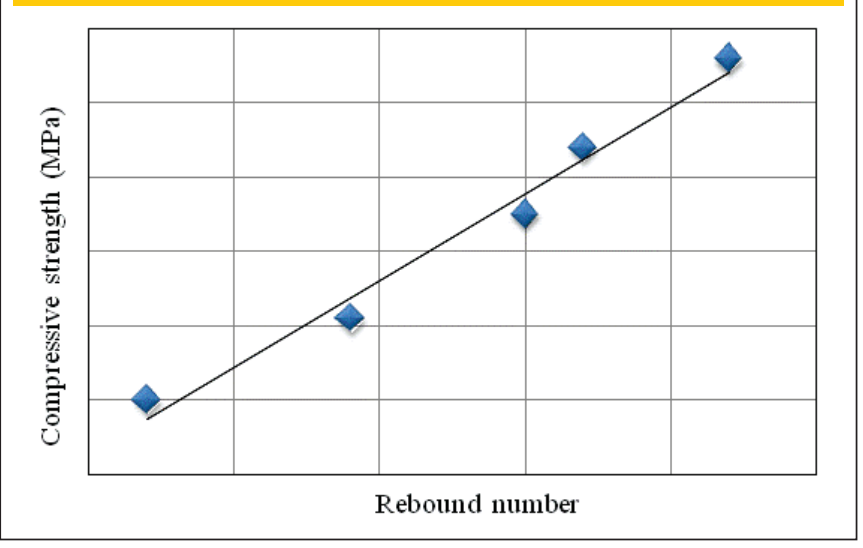

is a spring, a plunger and a hammer. The plunger is put in contact with the concrete surface so as to move the hammer inside the cylindrical tube and the spring is extended. When the hammer comes to the end of the tube, a device releases the equipment so that, by action of the spring, it strikes the piston and rebounds for a given extent. Because of the impact effect, the mass returns by a certain magnitude generating an index pointed by a cursor that moves along a graduated scale [Figure 1]. The rebound number is proportional to the distance traveled by the mass on rebound and resistance of concrete is directly proportional to the distance that the mass is reflected inside the unit after the impact.

The readings by rebound hammer are quite sensitive to local variations in the concrete, especially aggregates, holes near the surface and discontinuities near the tested area. According to Malhotra [14], the most influencing factors in the results of the rebound hammer test are the type of surface treatments aggregate, rebound hammer inclination, carbonation of the outer layers of concrete, age of structure, humidity, type of cement and proportioning of the concrete.

According to the $\mathrm{ACl} 228.1 \mathrm{R}$ [15], the test provides an estimate of the outer structural element surface hardness (about 2-3 cm from the surface). Although a superficial assessment, in most cases the standard reports as satisfactory the relationship between the rebound number and the compressive strength of concrete, which justifies the usual application in engineering analysis.

According to Machado [16] and Evangelista [17], the estimate of the compressive strength of concrete, in tests on specimens with the rebound hammer, has a reliability of $\pm 20 \%$ and the average coefficient of variation is approximately $10 \%$. However, for Malhotra [14], these tests should be viewed as an additional technique, and not as substitutes for destructive testing.

The equipment used in the tests provides correlation curves between the rebound value and concrete strength. The NBR 7584 [11] recommends the use of appropriate correlation curves obtained through tests on materials in the region where the concrete was manufactured, when one wants to use the rebound hammer to evaluate concrete resistance to compression , guaranteeing thus safer results. Second, the rebound hammer test is established and widespread, for the DNER [18] there is already a consolidated experience on the procedure, including correlation curves (rebound number versus strength of concrete provided with the equipment) very reliable.

This is a very controversial issue, because the current legislation in Brazil recommends that generic curves are not to be applied to all kinds of concrete. On this issue, these authors favor the view that the most reliable way to make use of the rebound hammer is associating the compression tests on specimens extracted from the site inspected. That is, to adopt the practice of using the correlation curves is not exactly a general practice. So, correlation curves must be developed for each structure inspected, with the realization of rebound hammer at some points, associated with the extraction of specimens and further rupture test. This allows the construction of a correlation between the rebound number and compression strength obtained in the same points, allowing the construction of a correlation curve similar to that shown in Figure 2. These curves are used to evaluate compression strength at points where only rebound hammer was performed. This practice prevents the extraction of excessive amounts of specimens, which is a technique that causes more damages to parts and is more expensive for inspection work in the structures.

The rebound hammer test has other applications besides the quantitative measure of the concrete strength. Castro et al. [19] points it out as useful for the evaluation of the mechanical strength uniformity with very little damage to structural elements, allowing comparison between different parts of the structure. It is also possible to estimate the evolution of concrete strength in precast structures, application of loads on new structures, and verification of resistance to service loads on damaged structures [9].

\subsection{Ultrasound test}

The first studies based on the measurement of waves propagation speed, generated mechanically, date from the mid 40 s. These studies demonstrate that the speed of propagation is correlated to the elastic properties and material density. The studies also indicate that the propagation speed is almost independent of the geometry element. The test has been developed up to the current process of measuring the ultrasound propagation speed with equipment consisting of circuits able to generate and register waves within a frequency of $20-150 \mathrm{kHz}$ [6].

At the present, the commercialized equipment consists of a central unit, which has an electrical pulse generator, a pair of transducers, transmitter, receiver, amplifier and an electronic device for measuring the time between the peak of the pulse generated in the transmitter transducer (maximum amplitude) and the arrival of the peak to the receiving transducer.

Ultrasound wave propagation speed measurement is proabably more applicable than any of the non-destructive tests. Its main applications are the determination of the concrete homogeneity, evaluation of existence and estimate of depth of cracks, the existence of large voids or holes, estimation of the compressive strength and determination of the elastic modulus.

The speed of the pulse of longitudinal waves produced on the test depends on the elastic properties of the material - such as elastic modulus and Poisson's ratio - and its density, as quoted by Castro et al. [19] and $\mathrm{ACl} 228.2 \mathrm{R}$ [20]. The dependence on material properties and the behavior of the waves that travel through the material allows correlation that can be used, for example, to determine the mechanical strength of the concrete. 


\section{Figure 3 - Pull Off test: (a) Test in progress and (b) equipment}
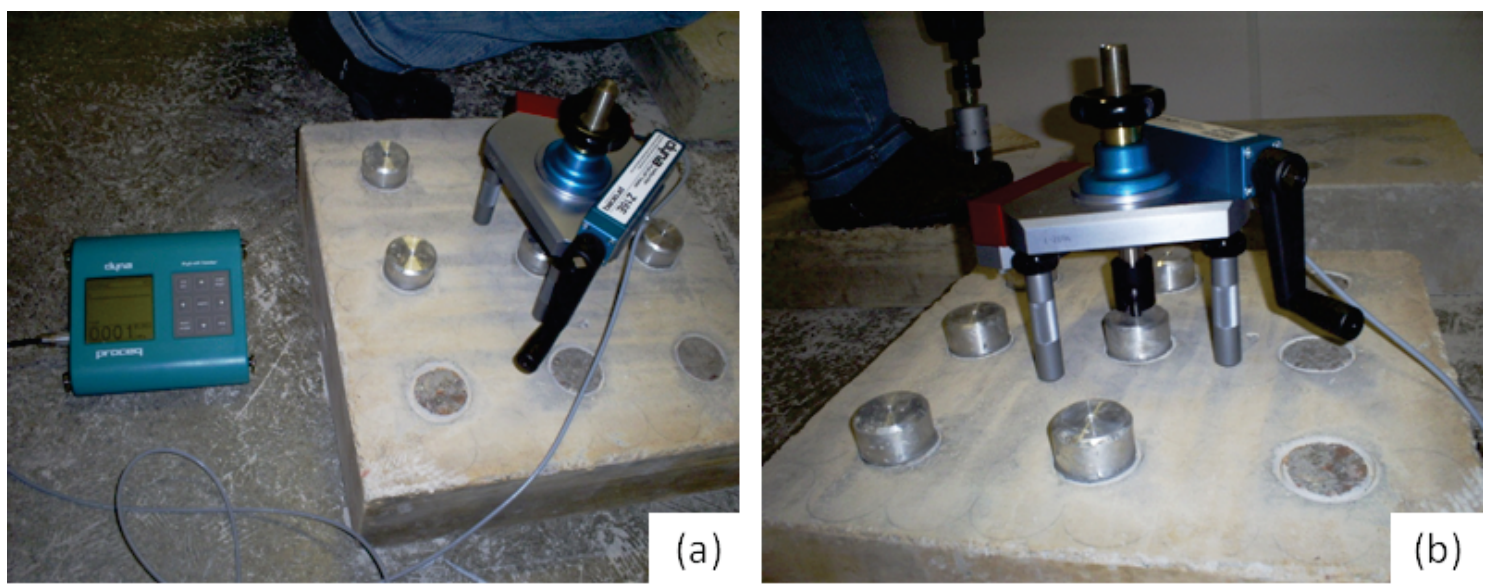

Grullón et al. [21] in their paper for evaluating the strength of concrete using ultrasound for different mix proportion of concrete and humidity condition got a low sensitivity for this evaluation. For strength of specimens ranging between 41 and $64 \mathrm{MPa}$, the speed of ultrasound propagation ranged from $4425-4721 \mathrm{~m} / \mathrm{s}$, with very close values, susceptible to experimental errors.

Machado et al. [22], using rebound hammer tests, penetration resistance and ultrasound to determine concrete strength, concluded that ultrasound showed the lowest correlation for obtaining the resistance. Popovics et al. [23] mentions that the estimate of resistance cannot be obtained with high accuracy using just the value of the ultrasound test. The author reports a lack of theoretical relationship between the magnitudes listed, although in other tests that also happens.

The propagation speed can be influenced by several factors being the most important: the run length, size of the structure to be tested, the presence of reinforcement, as well as temperature and humidity condition of the concrete. Results with high accuracy are influenced by preparation of surface to be tested, binding of the transducers and the method of selection and placement of transducers.

\subsection{Pull Off}

The Pull Off test was developed in England in the 70s, with the aim of determining the strength of concrete in situ, due to problems with concrete produced with high-alumina cement [5]. The test has been used successfully since then to evaluate the resistance of concrete. This test can also be used to verify the adhesion strength of the concrete repairing material [24].

The Pull Off test is not standardized in Brazil, but countries like England and USA recognize this method as a possibility in studies to estimate the compressive strength in the field [13]. This approach has revealed consistent results; in addition, the unsatisfactory results are visible after the test by observing the rupture surface.

Due to its simplicity, the test may be performed in the structure, including without planning prior to concreting. The technique is effective for use in beams and slabs and also shows appropriate application in structural elements of short section. One exposure face of the element is enough to testing. Another important point is the fact that the equipment used in the implementation of Pull Off is the same used in adhesion assays in mortar, standardized in Brazil for some years, which may facilitate its use.

The Pull Off test is based on the concept that the traction force required to pull a metallic disc bonded to a surface layer of concrete is associated with the compressive strength of the material [19]. In the test, the traction is axially transmitted to the disc previously bonded to the concrete. After a period of time enough to cure the resin (adhesive), a traction force is applied to the disc using a mechanical portable system [Figure 3 (a) and 3 (b)]. The gradual increase of force (Megapascal (MPa)) can be observed in equipments that have an integrated digital manometer. The tensile force that causes breakage associated with the calibration curves makes possible to estimate the compressive strength [5].

There are many factors that may influence the results obtained and are responsible for variability in this test. In addition to the composition and concrete properties, also have influence the variation on the rupture surface, the orientation and position of the aggregate onto the disc, the disc material (steel or aluminum), the disc diameter and thickness (ratio e/d), the backpressure system (ring or tripod) and the speed of load application [7].

In Brazil, the Pull Off test is traditionally used to evaluate the adhesion strength of mortar. A difference of this test applied to concrete and mortar is the presence of coarse aggregate which becomes an influencing factor. It is thought that the shape and position of the aggregate over the disc surface influence the results, but this is an issue that requires further studies to determine the conditions of this variable.

Another factor of interference in the results is the presence of reinforcement in the area where the metallic disc is bonded to the test performance. The lack of control of this variable could cause distortions in the results damaging the efficiency of the inspection. Therefore, it is recommended that before bonding the discs, a locator is used to ensure that the disc is not bonded in areas where the presence of reinforcement occurs. 


\subsection{Advantages and disadvantages of the three tests}

Among the advantages of the rebound hammer test is the ease of operation, lightness, speed of execution and little damage to the concrete structure inspected. As disadvantages of this method may be mentioned that the measure performed refers to a surface layer of concrete (about $30 \mathrm{~mm}$ ). Furthermore the structures, after three months of age, suffer the influence of concrete carbonation which densifies the region carbonates and raises the values of the rebound number $[25,15]$.

Compared to other methods, the rebound number can be applied in slender elements, and, for this situation, it is more advantageous than other methods such as extraction of specimens. In these cases, it is advised to use the rebound hammer used in conjunction with other techniques to confirm the elements homogeneity [26]. The ultrasound test is also a possibility as a portable and fast execution. Compared to rebound hammer this technique has the advantage of providing results which represent the material as a whole and the reading is executed directly. This minimizes the influence of the carbonated layer, often observed in the inspection. Comparing costs, this method involves equipments about 4 times more expensive than the rebound hammer.

An important disadvantage of the ultrasound test is the different influence of humidity on the results in resistance to compression tests on specimens extracted and squeezed. The higher humidity content of concrete, the greater the speed of propagation of ultrasound and the lower the values of compressive strength of extracted specimens. This detail is important in developing correlation curves of the speed of ultrasound versus compressive strength for estimates in the whole building.

Another disadvantage is the influence of reinforcement, because the speed of propagation of waves in the carbon steel is much higher than in the concrete [27]. Therefore, the presence of reinforcement increases the value of ultrasound speed propagation, concealing the results.

Comparing Pull Off test with rebound hammer or ultrasound, the Pull Off increases the time for test because depends on bonding a metallic disc on the surface of the concrete. The execution of the hole in the concrete surface, if this practice were adopted, also involves the disadvantage of consuming more time and the use of other equipment (drill and saw cup) for inspection. However, this detail can also be cited as an advantage, because it has the possibility of executing the hole through the carbonated layer, eliminating this factor that influenced the measurements. The cost of the equipment is in the same order of ultrasound equipment, meaning that it is more expensive than the rebound hammer.

As a disadvantage can be cited the need for local repairs where the tests were executed since the concrete in the area suffers surface fractures. It should be also considered the delay time for the curing of the resin used for bonding the disc prior to application of load. This time varies between 1.5 and $24 \mathrm{~h}$, depending on the adopted type of adhesive. The resin most frequently used is epoxy. Another limiting factor for application of this test is the impossibility of its execution in high-strength concrete due to load limitations equipment availability. As an example, the equipment used in this study (Dyna Z16E Proceq) with maximum traction of $16 \mathrm{kN}$, this means, to a disc of $5.0 \mathrm{~cm}$ a maximum tensile stress of $8.15 \mathrm{MPa}$. This means that for this equipment, it would be possible to estimate the concrete compressive strength of up to about $80 \mathrm{MPa}$, whereas the tensile strength is about $10 \%$ of the compressive strength of concrete. However, as the conventional concrete today have a compressive strength between 20 and $35 \mathrm{MPa}$, the method can be used in most of the cases of practical application of Portland cement concrete.

The aim of this study is to compare the accuracy of the methods discussed, as there is distrust about both nationally standardized techniques (rebound hammer and ultrasound). As an example, Evangelista [17] and Castro [28] reported the low accuracy of the rebound hammer test when correlated with compressive strength. Grullón et al. [21] reported a low correlation between speed of wave propagation and compressive strength. Furthermore, Machado et al. [22], using the rebound hammer, penetration resistance and ultrasound to determine the strength of concrete, concluded that ultrasound had the worst results as the correlation to obtain the resistance.

Thus, the focus of this work is to verify if the Pull Off test has better

\section{Table 1 - Chemical compositions and physical properties of cement}

\begin{tabular}{|c|c|c|c|c|c|c|c|c|c|c|}
\hline \multicolumn{11}{|c|}{ (a) Chemical composition } \\
\hline Cement & $\begin{array}{l}\mathrm{SiO}_{2} \\
(\%)\end{array}$ & $\begin{array}{c}\mathrm{Al}_{2} \mathrm{O}_{3} \\
(\%)\end{array}$ & $\begin{array}{c}\mathrm{Fe}_{2} \mathrm{O}_{3} \\
(\%)\end{array}$ & $\begin{array}{l}\text { CaO } \\
(\%)\end{array}$ & $\begin{array}{l}\text { MgO } \\
(\%)\end{array}$ & $\mathrm{SO}_{3}(\%)$ & $\begin{array}{l}\text { Ignition } \\
\text { loss (\%) }\end{array}$ & $\begin{array}{c}\text { Free lime } \\
(\%)\end{array}$ & $\begin{array}{l}\text { Insoluble } \\
\text { residue (\%) }\end{array}$ & $\begin{array}{c}\text { Total alkalies } \\
\text { as } \mathrm{Na}_{2} \mathrm{Oe}^{*}\end{array}$ \\
\hline CP II-F-32 & 18.35 & 4.07 & 2.54 & 59.64 & 5.19 & 3.07 & 5.35 & 1.2 & 1.47 & 0.63 \\
\hline
\end{tabular}

\begin{tabular}{|c|c|c|c|c|c|c|c|c|}
\hline \multicolumn{9}{|c|}{ (b) Physical and mechanical properties } \\
\hline \multicolumn{2}{|c|}{ Setting time } & \multirow{2}{*}{$\begin{array}{l}\text { Blaine's specific } \\
\text { surface area } \\
\text { Blaine }\left(\mathrm{cm}^{2} / \mathrm{g}\right)\end{array}$} & \multirow{2}{*}{$\begin{array}{l}\text { Residue on } \\
\# 200(\%)\end{array}$} & \multirow{2}{*}{$\begin{array}{l}\text { Residue on } \\
\# 325(\%)\end{array}$} & \multicolumn{4}{|c|}{$\begin{array}{l}\text { Compressive strength of mortar } \\
\text { (MPa) }\end{array}$} \\
\hline (h:min) & (h:min) & & & & 1 day & 3 days & 7 days & 28 days \\
\hline $3: 31$ & 4:10 & 3.338 & 3.87 & 17.76 & 11.1 & 25.1 & 32.0 & 40.4 \\
\hline
\end{tabular}




\section{Figure 4 - Particle size distribution of the fine aggregate}

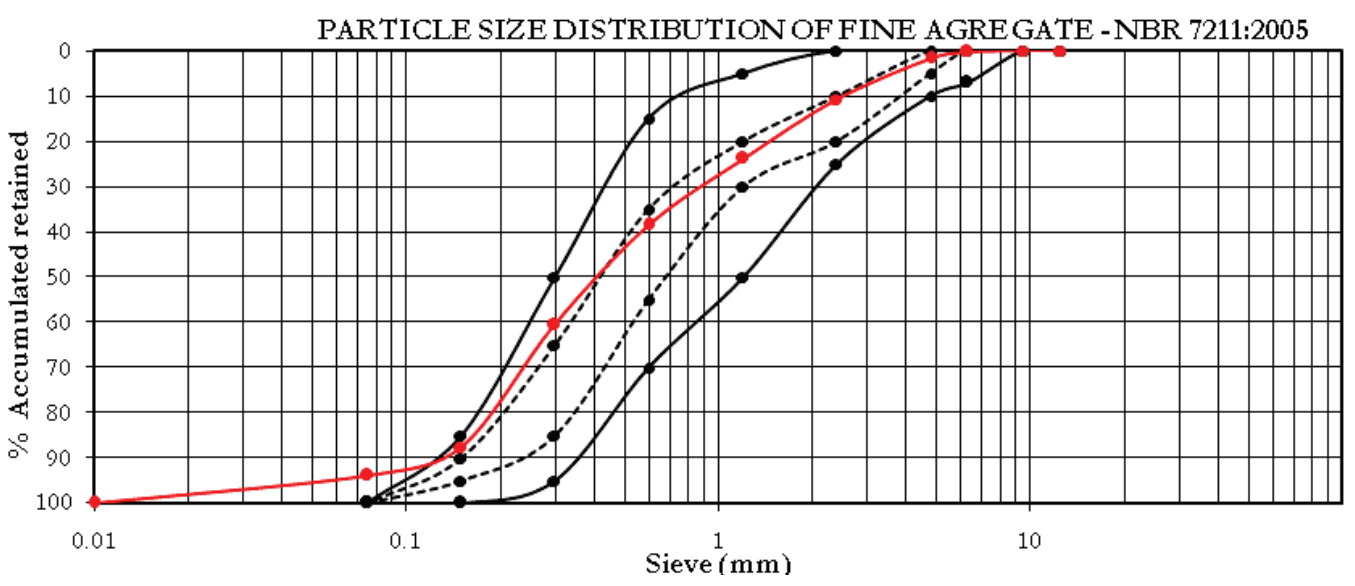

correlation with the compressive strength of the two tests standardized by the Brazilian Association of Technical Standards (ABNT).

\section{Experimental procedure}

The experimental procedure of this research investigated the effectiveness of NDT as a tool for assessment of concrete strength compared to the results obtained by simple compression of prismatic and cylindrical specimens. For this, the rebound hammer and ultrasound tests were selected, standard in Brazil and the Pul Off test, presented in this paper as an alternative to popular tests for structures evaluation.

\subsection{Materials}

The cement used was a CP II F-32. The chemical composition and the physical and mechanical characterization of the cement are shown in Table 1.

Fine aggregate was natural river sand with 2.23 fineness modulus. Coarse aggregate is of a limestone with $25.0 \mathrm{~mm}$ nominal maximum size. Figures 4 and 5 show the size distribution curves of these aggregates.

\subsection{Description of study variables}

Initially, a proportion of concrete mixtures with three different water/ cement ratios $(0.43,0.5$ and 0.59$)$ was used. Using these concrete mixtures prismatic and cylindrical specimens were prepared for simple compression, rebound hammer and ultrasound tests. For the Pull Off test one concrete slab for each water/cement ratio was molded. The tests were conducted in the Structures and Materials Laboratory, located on the campus of the Federal University of Paraná.

Figure 5 - Particle size distribution of the coarse aggregate

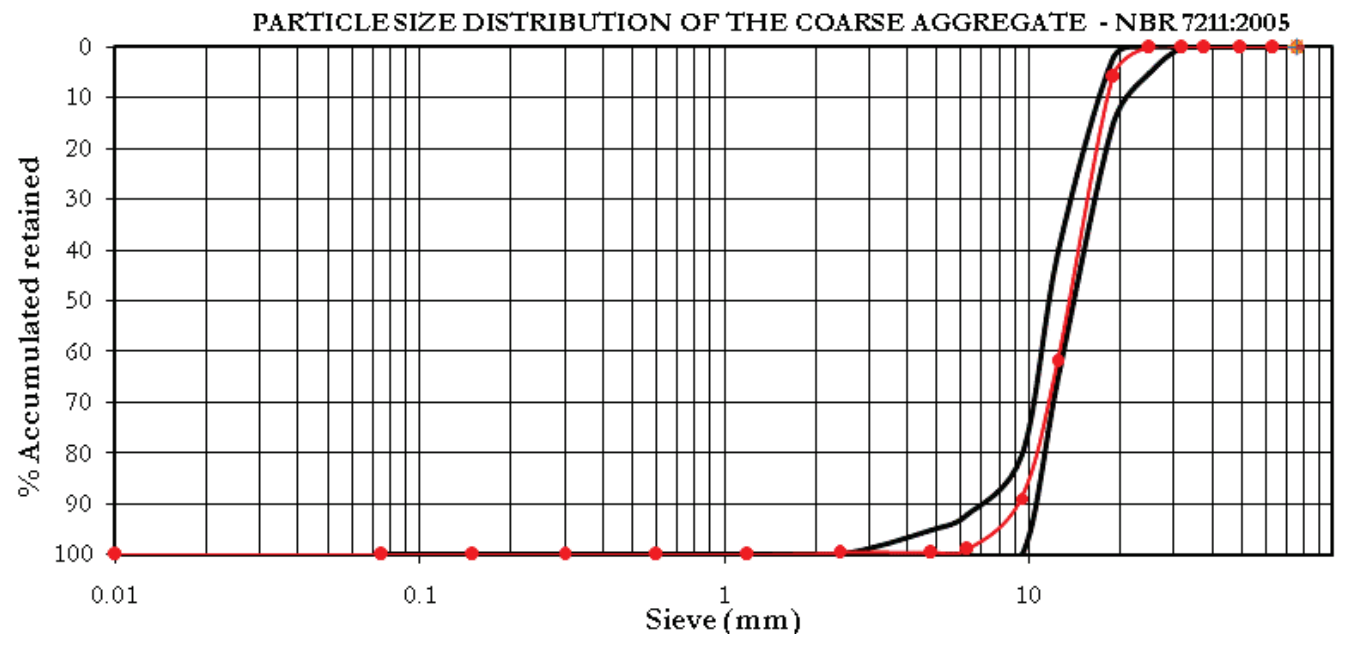


Table 2 - Mix proportions of concretes

\begin{tabular}{ccc|}
$\begin{array}{c}\text { Cement: } \\
\text { aggregates }\end{array}$ & $\begin{array}{c}\text { Cement : } \\
\text { fine aggregate : } \\
\text { coarse aggregate : } \\
\text { w/c }\end{array}$ & Slump $(\mathrm{mm})$ \\
$1: 3$ & $1: 1.08: 1.92: 0.43$ & 105 \\
$1: 4$ & $1: 1.60: 2.40: 0.50$ & 90 \\
$1: 5$ & $1: 2.12: 2.88: 0.59$ & 95 \\
\hline
\end{tabular}

\subsection{Proportioning concrete}

For proportioning the concrete used in the study, it was used the IPT/EPUSP experimental method of concrete proportioning, also called the four quadrants method. This method is based on the laws of Lyse, Abrams and Molinari, adjusted on resistance and workability curves depending on structural requirements. The Slump was set to $100 \pm 10 \mathrm{~mm}$ and the mortar content of $\alpha=52 \%$. Data about proportioning and consistency of the material are shown in Table 2. Mineral addition and superplasticizer admixture were not used in the concrete composition.

For each mix proportions of concrete was molded a prismatic slab of $55 \mathrm{~cm} \times 55 \mathrm{~cm} \times 20 \mathrm{~cm}$ for the Pull Off test, 6 cylindrical specimens of $15 \mathrm{~cm} \times 30 \mathrm{~cm}$ and 6 prismatic specimens with $15 \mathrm{~cm}$ $x 15 \mathrm{~cm} \times 15 \mathrm{~cm}$ for simple compression, rebound hammer and ultrasound test.

To ensure homogeneity of the mixture, all the concrete used in this study was made by a concrete mixer with an inclined axis and a capacity of 240 liters. The consolidation of concrete was executed in a vibrating table and completion of the specimen in two layers of concrete for both cylindrical and prismatic specimens. Each layer was submitted to a cycle of 20 seconds for consolidation on the vibrating table.

After molding, the specimens were cured in a humidity chamber (95\% relative humidity and $23 \pm 2{ }^{\circ} \mathrm{C}$ temperature) according to NBR 5738 [29], for 112 days. The choice of a high age for the testing of resistance is due to the fact that the structures tests are designed to evaluate old structures with a high degree of hydration. Therefore, testing in high ages has greater correlation when compared to practice.

\subsection{Speed of propagation of ultrasound waves}

After curing the specimens, ultrasound tests were performed on all specimens according to NBR 8802 [12]. Initially, 24 hours before the test, the specimens were removed from the chamber to surface drying in a laboratory environment. Before starting the tests the surfaces of the specimens were verified to ensure these were dry and flat.

The transducers were positioned on opposite faces of the specimens, as observed in Figure 6. The contact between the transducer and the concrete surface was conducted with ultrasound gel with the aim of producing a near perfect coupling. For the same place, the highest pulse propagation velocity was regarded as the representative value of the test specimen, since this value is interpreted as the closest perfect coupling obtained in reading.

The end result of each test was derived from the average of the six representative readings of specimens of each concrete studied.

\subsection{Rebound hammer}

After the ultrasound test, the specimens were tested with the rebound hammer. For implementation of the rebound hammer, the equipment used was a model of CT-320AM Soiltest.

In the procedure followed in this research, the first step was to test a specimen compression according to NBR 5739 [1]. This practice aimed to determine the concrete resistance to calculate the load value that would be applied to the specimens for the implementation of the rebound hammer test, as the NBR 7584 [11] determines to be applied to the specimens a load of approximately $15 \%$ of its rupture load to restrict movements in specimens during testing. Thus, by knowing approximately the concrete strength, the other five cylindrical specimens intended for rebound hammer test and compressive strength were previously loaded with $15 \%$ of their maximum resistance and the determination of the rebound number was performed.

In each specimen, both prismatic and cylindrical, nine rebound numbers were obtained. Figure 7 (a) shows the execution of a test specimen. In the case of test cylinders, each specimen was labeled in three parts of $120^{\circ}$ where in each one three readings were performed, one in the center, one in the upper end and another at the lower end of the specimen [Figure 7 (b)]. In the prismatic, nine readings were performed on the same face as can be seen in Figure 7 (c).

\subsection{Compressive strength test}

After execution of the rebound hammer and ultrasound tests, the cylindrical and prismatic specimens were tested for simple compression. For the capping of the specimens sulfur was used. The concrete press machine was an EMIC with application load speed control.

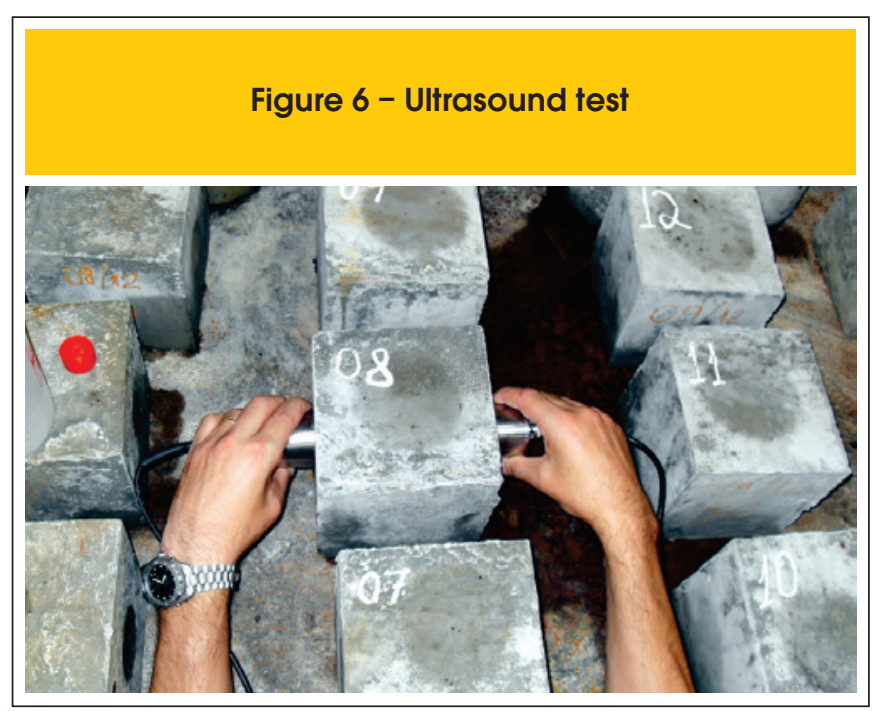




\section{Figure 7 - a) Rebound hammer; b e c) Measurement points in the specimens}
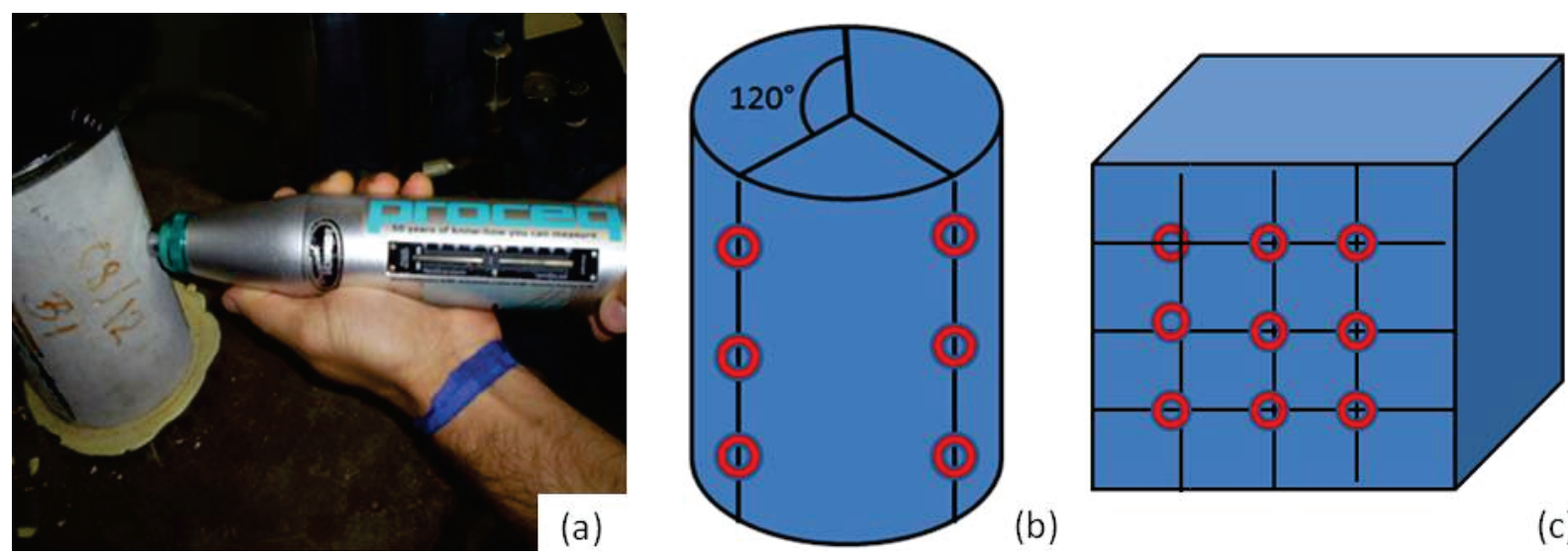

(b)

(c)

The simple compression test on cylindrical specimens was performed following the procedures proposed in NBR 5739 [1] [Figure $8(\mathrm{a})]$. The simple compression test on prismatic specimens was performed according to BS 12390-3 [3] [Figure 8 (b)]. For both tests was adopted the loading speed of $0.4 \mathrm{MPa} / \mathrm{s}$.

\subsection{Pull Off test}

The Pull Off test applied to concrete is not standardized in Brazil. This study adopted the recommendations of BS 1881: Part 207 [13]. In this method, the traction is axially transmitted to a metallic disc bonded beforehand into the concrete surface. After a period of time enough to cure the epoxy resin used for bonding the discs, a tensile force is applied to the disc using a portable mechanical system [Figure $3(\mathrm{a})$ ]. The gradual increase in tension can be directly observed on a scale (MPa), and the maximum tension is logged, as soon as the pullout of concrete happens. The equipment used for the tests was the Dyna Z $16 \mathrm{E}$ Proceq [Figure 3 (b)].

For implementing the Pull Off test concrete slabs of $55 \mathrm{~cm} \times 55$ $\mathrm{cm} \times 20 \mathrm{~cm}$ molded in the laboratory with the same concrete used in the specimens of the resistance test were used. Nine readings were performed on each slab. The amount of readings in each slab was defined by recommendations of BS 1881: Part 207 [13]. Another factor in the sizing of the slabs is the recommendation from the standard that discs should be set at a minimum of two diameters to each other and positioned at a distance of a diameter from the edges of the element to be tested. The material of the discs used in the assay is aluminum and its dimensions are $25 \mathrm{~mm}$ high and $50 \mathrm{~mm}$ in diameter.

The test was conducted with a surface cut of $5 \mathrm{~mm}$ deep according to the dimension of the metallic disc. The execution of the cutting was done to avoid the influence of the surface conditions of the concrete, as in the case of carbonated surfaces.

Figure 8 - Compressive strength test (a) cylindrical specimens and (b) cubic specimens
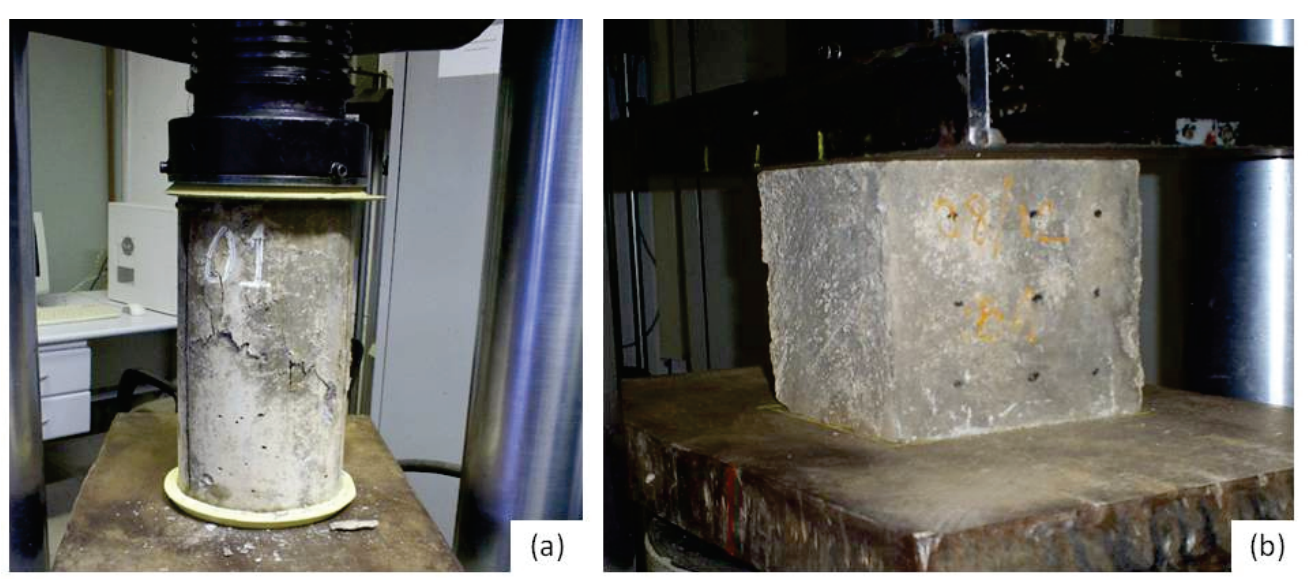
Table 3 - Gathered data in non-destructive tests and compressive strength test using cylindrical and cubic specimens

\begin{tabular}{|c|c|c|c|c|}
\hline \multirow[b]{2}{*}{ Concrete } & \multicolumn{4}{|c|}{ Cubic specimens (15 x 15 x 15cm) } \\
\hline & $\begin{array}{l}\text { Rebound hammer } \\
\text { (MPa) }\end{array}$ & $\begin{array}{l}\text { Ultrasound test } \\
\text { (MPa) }\end{array}$ & $\begin{array}{l}\text { Pull Off } \\
\text { (MPa) }\end{array}$ & $\begin{array}{l}\text { Compressive strength } \\
\text { (MPa) }\end{array}$ \\
\hline Low cement content & 31 & 4511.2 & 1.91 & 30.32 \\
\hline Intermediate cement content & 38 & 4635.2 & 2.8 & 37.83 \\
\hline High cement content & 40 & 4702.5 & 3.08 & 44.63 \\
\hline \multirow[b]{2}{*}{ Concrete } & \multicolumn{4}{|c|}{ Cylindrical specimens $(\varnothing 15 \times 30 \mathrm{~cm})$} \\
\hline & $\begin{array}{l}\text { Rebound hammer } \\
\text { (MPa) }\end{array}$ & $\begin{array}{l}\text { Ultrasound test } \\
\text { (MPa) }\end{array}$ & $\begin{array}{l}\text { Pull Off } \\
\text { (MPa) }\end{array}$ & $\begin{array}{l}\text { Compressive strength } \\
\text { (MPa) }\end{array}$ \\
\hline Low cement content & 37 & 4570.5 & 1.91 & 30.00 \\
\hline Intermediate cement content & 36 & 4613.8 & 2.8 & 38.87 \\
\hline High cement content & 46 & 4641.5 & 3.08 & 45.73 \\
\hline
\end{tabular}

Before starting up the bonding of metallic discs in the concrete surface, the surfaces were prepared to obtain good adhesion. This procedure is adopted mainly for removal of the cement paste on the concrete surface and to make the aggregate apparent. A caution was taken so that the place of bonding was plain enough to ensure that the adhesive is present in the entire contact surface between the disc and the concrete, ensuring that the strength is applied uniformly throughout the area of bonding. To regularize this site was used a sander with fine sandpaper. The bonding was performed with a thin layer of adhesive and the surplus concentrated around the disc was removed still fresh, thus ensuring that the rupture surface had the area of the disc. An epoxy resin was used as adhesive with curing time of 24 hours.

\section{Results and discussion}

Initially, the test results obtained in the experimental program were treated statistically in order to eliminate spurious values, which could compromise the validity of analyzes.

For the rebound hammer tests nine readings on each specimen were determined, being considered a valid reading when at least five individual values did not differ from average by more than $10 \%$. According to NBR 7584 [11], the values outside the range were discarded and the average was recalculated only with valid values. This procedure was performed on five specimens of the same concrete. At the end of the preliminary treatment, the final result was calculated as the simple average of the final values obtained from valid samples.

To prismatic and cylindrical specimens tested in compression and in ultrasound tests, it was considered the average of the six specimens. The Pull Off test is not standardized in Brazil and therefore in this study were used the recommendations of BS 1881 Part 207 [13]. Nine points in each specimen were tested, being considered valid if at least six individual values did not differ from the mean \pm one standard deviation. All specimens were within this limit. The pullout strength was obtained with the average of the valid values after the initial treatment.

The average values of compressive strength, ultrasound test, Pull Off test and rebound hammer after pretreatment are shown in Table 3.

With the data in Table 3 were created graphs to demonstrate the correlation between the non-destructive tests and the compressive strength of cylindrical and cubic specimens for the three concrete mixtures studied. Figure 9 refers to the correlation between the compressive strength and the rebound number.

In Brazil, the rebound hammer is the most popular non-destructive test, but some researchers question the effectiveness of the method to accurately estimate the concrete strength. Rebound hammer data show a direct relationship between the compressive strength results and the rebound number. Moreover, there is a weak cor-

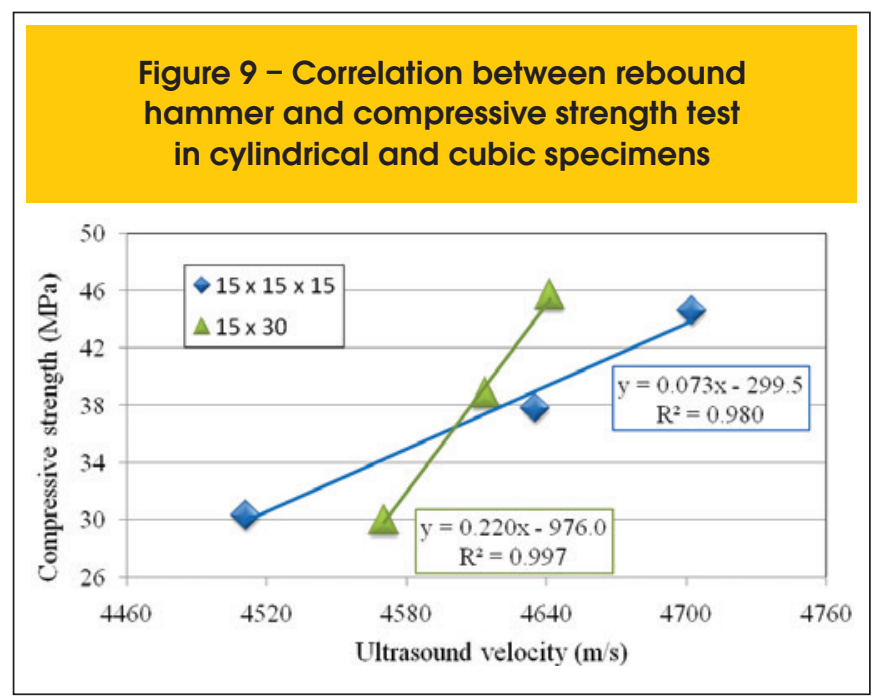




\section{Figure 10 - Correlation between ultrasound test and compressive strength test in cylindrical and cubic specimens}

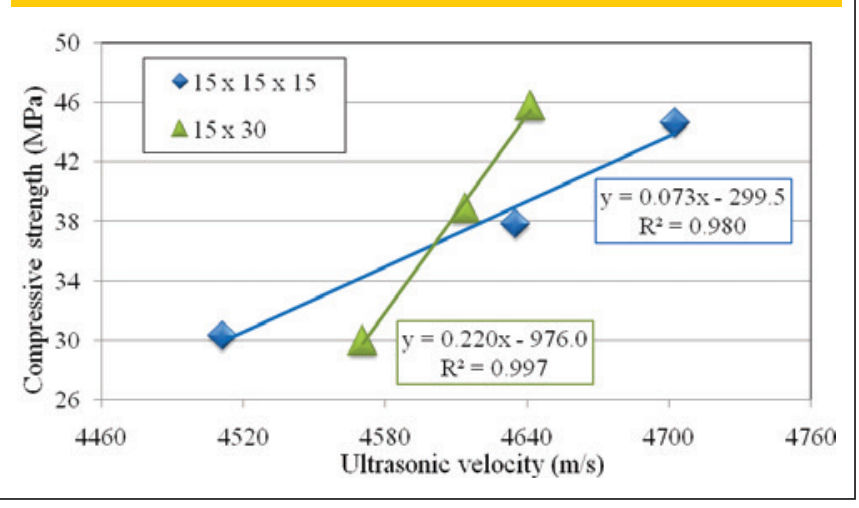

relation $\left(R^{2} \approx 0.60\right)$ when the analysis is conducted with cylindrical specimens, as standardized in Brazil.

For the rebound hammer test conducted in prismatic specimens the correlation increases significantly $\left(R^{2}=0.92\right)$. A possible explanation for this difference may be the fact that in cylindrical specimens the impact of the rebound hammer is applied to a surface that is not flat, unlike the case of prismatic. It is possible that this detail may adversely affect the results, but studies have yet to be made to better understand this influence, as the uncertainties about the efficiency of the rebound hammer remain.

In Brazil, a complementary method to rebound hammer is the ultrasound test [12]. Thus, Figure 10 shows results of this kind of test. Results of ultrasound test using two types of specimen (cubic and cylindrical) showed a very good correlation with the compressive strength $\left(R^{2}>0.98\right)$. The ultrasound test performed on cylindrical specimens showed correlations very close to the tests performed on prismatic. This confirms the assumption discussed above about the test being performed on curved surfaces that could adversely affect the results. In ultrasound test the propagation velocity of sound waves is measured on the flat faces of cylindrical specimens and possibly for this reason the results obtained in both types of specimens (cubic and prismatic) show similar correlations. Nonetheless, the propagation velocity has a strong influence from the shape of the specimens, since to the same concrete mix proportion there is a large difference in response between the cylindrical and cubic specimens.

Albeit the higher accuracy obtained with the ultrasound test, the required equipment is more costly than the rebound hammer, for example. Alternatively to ultrasound and rebound hammer test, there is the Pull Off test, which although it is also expensive, uses the same equipment used to bond strength measurement between mortar coating and masonry substrate. Figure 11 shows the correlation between the results of Pull Off test obtained by pulling on the surface of concrete and compressive strength measured in specimens molded with the same concrete of prismatic plates.

Analyzing the values obtained in the experimental program and the graphs, it can be concluded that the Pull Off test (in situ test) shows consistent results for comparison with the concrete strength results obtained in laboratory being a suitable tool to evaluate the strength of concrete in situ.
This check is based on the observation of correlation with compressive strength tests (both with $\mathrm{R}^{2}$ above 0.93 ), which, under the technical point of view, would enable the test analyzed in this work to be used for analysis of concrete strength. In this case, it is important to say that the estimative of the compressive strength by Pull Off test leads to very similar results for both cubic and cylindrical specimens, which did not occur with rebound hammer and ultrasound tests.

The execution of the test was simple, which indicates that compared to other non-destructive tests, the Pull Off test does not have very complex details and can be performed by an employee with a simple training, as in the case of the rebound hammer and ultrasound tests. The fact that the equipment is simple to operate and being the same used for testing the bond strength of mortar coatings, the availability of equipment and staff to run the test becomes easier.

\section{Conclusions}

Non-destructive tests are an appropriate and useful tool in monitoring concrete structures and estimating their strength in-place. The rational use of the various available methods, as well as a possible combination of more than one technique can be particularly interesting from the viewpoint of the results validity.

The rebound hammer method showed distinct correlation level with the compressive strength when measured in cylindrical or prismatic concrete specimens. A possible cause of distortion is the measurement in curved surfaces of cylindrical specimens. In general, it appears that studies on the efficiency and reliability of the rebound number results should also be better achieved. It is recommended that the rebound hammer is used as a complement to other in-place tests or in a preliminary stage of inspection.

With regard to the ultrasound test, it was found that it has excellent correlation $\left(R^{2}>0.95\right)$ with the compression strength of concrete for both cylindrical and cubic specimens. However, the behavior of the results appeared to be influenced by the shape of the specimens, which goes against the method theory.

The results obtained with the Pull Off test showed that it is fully feasible to be employed to estimate the strength of concrete in situ.

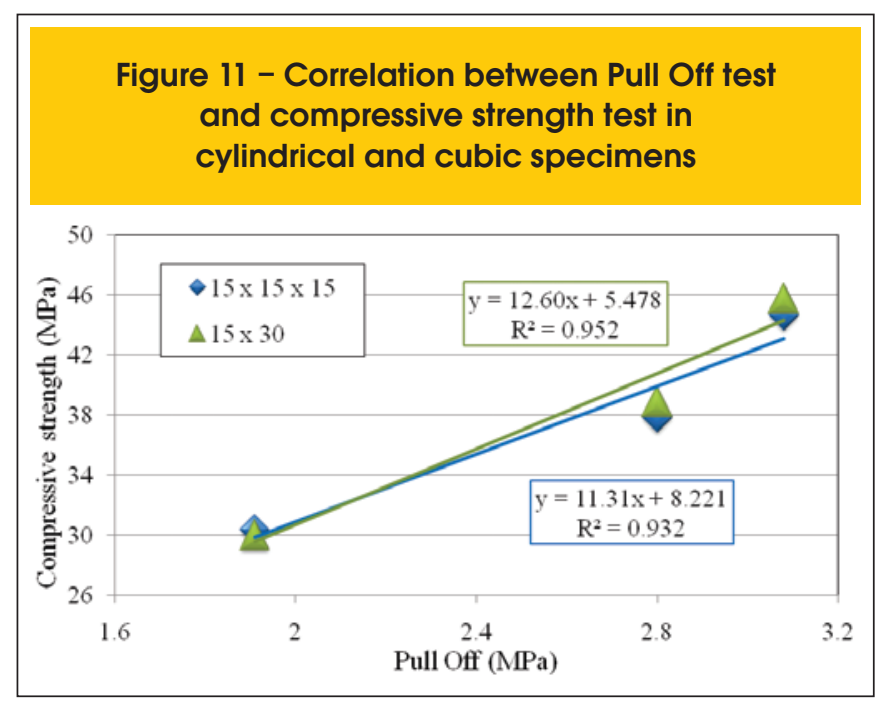


This statement is based on the correlation values with the compression strength test, both in cylindrical and prismatic specimens, compared to the values of Pull Off test (both with $\mathrm{R}^{2}$ above 0.93 ). Besides the high correlation found for the latter test, the Pull Off has the advantage that the same equipment is used to measure the bond strength in mortars. The experience in this area can be used in popularizing the test in concrete structures, since the procedures for carrying out the tests are similar. Thus, these authors recommend that this test should be the subject of study by other researchers in order to future standardization in Brazil, as it is already standardized in Europe.

\section{References}

[01] ASSOCIAÇÃO BRASILEIRA DE NORMAS TÉCNICAS. Concreto - Ensaios de compressão de corpos de prova cilíndricos. NBR 5739: 2007. Rio de Janeiro.

[02] AMERICAN SOCIETY FOR TESTING AND MATERIALS. Standard Test Method for Compressive Strength of Cylindrical Concrete Specimens. ASTM C39 / C39M. 2012.

[03] BRITISH STANDARDS INSTITUTION. Testing hardened concrete. Compressive strength of test specimens. BS 12390 part 3. 2002.

[04] BRITISH STANDARDS INSTITUTION. Testing concrete. Method for determination of compressive strength of concrete cubes. BS 1881 part 116. 1983.

[05] LONG, A. E.; MURRAY, A. The Pull-off Partially Destructive Test for Concrete, in: In-situ Non-destructive Testing of Concrete, SP-82, Detroit, American Concrete Institute, 1984.

[06] BUNGEY, J.H. The Testing of Concrete in Structures. Surrey University Press, 2nd Edition, Glasgow, 1989.

[07] PEREIRA, J. P. V. V. Avaliação da resistência à compressão do betão através de ensaios não-destrutivos. Dissertation (Master in civil engineering). Universidade de Coimbra. Coimbra - Portugal, 1999.

[08] NEPOMUCENO, M. C. S. Ensaios não destrutivos em betão. Dissertation (Master in civil engineering). Universidade da Beira Interior. Covilhã - Portugal, 1999.

[09] MEDEIROS, M.; BARBOSA, P.; GRULLÓN, M.; HELENE, P. Influência da dosagem do concreto na correlação entre resistência à compressão e índice esclerométrico. In: 46. Congresso Brasileiro do Concreto, 2004, Florianópolis. 46. Congresso Brasileiro do Concreto. São Paulo : Instituto Brasileiro do Concreto, 2004. v. II. pp. 1065-1072.

[10] PEREIRA, E; FREZ, J. C; MEDEIROS, M. H. F. Estimativa da resistência do concreto em campo: ensaios normalizados ou não no Brasil. Concreto e Construção, v. 63, p. 88-96, 2011.

[11] ASSOCIAÇÃO BRASILEIRA DE NORMAS TÉCNICAS. Concreto endurecido- avaliação da dureza superficial pelo esclerômetro de reflexão. NBR 7584. Rio de Janeiro, 1995.

[12] ASSOCIAÇÃO BRASILEIRA DE NORMAS TÉCNICAS. Concreto endurecido - Determinação da velocidade de propagação de onda ultra-sônica - NBR 8802. Rio de Janeiro, 1994.

[13] BRITISH STANDARDS INSTITUTION. Testing concrete. Recommendations for the assessment of concrete strength by near-to-surface tests. BS 1881 part 207. 1992.

[14] MALHOTRA, V.M. - In-situ/Nondestructive Testing of Concrete - A Global Review, In Situ/Nondestructive Testing of Concrete, SP-82, American Concrete Institute, Detroit, 1984.

[15] AMERICAN CONCRETE INSTITUTE. In-place methods for determination of strength of concrete. ACI 228.1R, Detroit, 2003.

[16] MACHADO, M. D. Curvas de correlação para caracterizar concretos usados no rio de janeiro por meio de ensaios não destrutivos. Dissertation (Master in sciences in civil engineeringl) - Universidade Federal do Rio de Janeiro. Rio de Janeiro, 2005.

[17] EVANGELISTA, A. C. J. Avaliação da Resistência do Concreto Usando Diferentes Ensaios Não Destrutivos. $\mathrm{PhD}$ thesys in Civil Engineering - Universidade Federal do Rio de Janeiro. Rio de Janeiro, 2002.

[18] DNER. Manual de inspeção de obra-de-arte especiais. Ministério dos Transportes - Departamento Nacional de Estradas de Rodagem. Rio de Janeiro. 1994.

[19] CASTRO, A. L; ÂNGULO, S. C; BILESKY, P. C; SANTOS, R. F. C. ; HAMASSAKI, L. T. ; SILVA, E. Métodos de ensaios não destrutivos para estruturas de concreto. Revista de Tecnologia da Construção Téchne (São Paulo), v. 17, pp. 56-60, 2009.

[20] AMERICAN CONCRETE INSTITUTE. Nondestructive test methods for evaluation of concrete in structures. ACI 228.2R, Detroit, 1998.

[21] GRULLÓN, M; BARBOSA, P; MEDEIROS, M; HELENE, P. Correlação entre resistência à compressão e ultrassom: influência da dosagem e da umidade. In: IBRACON 2004 - Volume II - Construções em Concreto - Trabalho CBC0101 - p. II.587 - II.596, 2004

[22] MACHADO, M. D; SHEHATA, L. C. D; SHEHATA, I. A. E. M. Curvas de correlação para caracterizar concretos usados no Rio de Janeiro por meio de ensaios não destrutivos. Revista IBRACON de Materiais e Estruturas - RIEM, pp. 100-123, volume II, número 2, 2009.

[23] POPOVICS, J. S.; SONG, W.; GHANDEHARI, M.; SUBRAMANIAM, K.V.; ACHENBACH, J. D.; SHAH, S. P. Application of surface wave transmission measurements for crack depth determination in concrete. ACI Materials Journal, 97, 2, p. 127-135, 2000.

[24] GONÇALVES, A. F. Novos ensaios não destrutivos para a determinação da resistência do betão nas estruturas. Laboratório Nacional de Engenharia Civil. Lisboa, 1986.

[25] BRITISH STANDARDS INSTITUTION. Determination of concrete strength by nondestructive method. BS 1881: Part 202. London, 1986. 
[26] HELENE, P. Análise da resistência do concreto em estruturas acabadas com vistas à revisão da segurança estrutural In: Revista de la Asociación Latinoamericana de Control de Calidad, Patología y Recuperación de la Construcción - ALCONPAT, pp. 67-92, volume 1, número 1, 2011.

[27] BUNGEY, J. H; SOUTSOS, M. N. Reliability of partially-destructive tests to assess the strength of concrete on site. In: Construction and Building Materials Maganize, p. 81-92, 2001.

[28] CASTRO, E. Estudo da resistência à compressão do concreto por meio de testemunhos de pequeno diâmetro e esclerometria. Dissertation (Master). Universidade Federal de Uberlândia. Uberlândia, 2009.

[29] ASSOCIAÇÃO BRASILEIRA DE NORMAS TÉCNICAS.

Concreto - Procedimento para moldagem e cura de corpos de prova. NBR 5738: 2003. Rio de Janeiro. 